\title{
PENGARUH PENDEKATAN CONTEXTUAL TEACHING AND LEARNING BERBASIS PENILAIAN PORTOFOLIO TERHADAP KOMPETENSI PENGETAHUAN IPA
}

\author{
Dw. Ayu Prami Handayani Dewi ${ }^{1}$, I Wayan Darsana ${ }^{2}$, I.B Surya Manuaba ${ }^{3}$ \\ 1,2,3 Jurusan Pendidikan Guru Sekolah Dasar, FIP \\ Universitas Pendidikan Ganesha \\ Singaraja, Indonesia \\ e-mail: handayani.dewi@undiksha.ac.id', iwayan.darsana@undiksha.ac.id ${ }^{2}$, \\ idabagussurya.manuaba@undiksha.ac.id ${ }^{3}$
}

\begin{abstract}
Abstrak
Penelitian ini bertujuan untuk mengetahui pengaruh pendekatan CTL berbasis penilaian portofolio terhadap kompetensi pengetahuan IPA siswa kelas V Gugus I Gusti Ngurah Rai Denpasar Selatan Tahun Ajaran 2017/2018. Jenis penelitian ini merupakan eksperimen semu dengan menggunakan rancangan penelitian Non-equivalen control group design. Populasi dari penelitian ini adalah seluruh siswa kelas V SD Gugus I Gusti Ngurah Rai Denpasar Selatan dengan jumlah populasi 263 siswa. Penentuan sampel dalam penelitian ini menggunakan teknik random sampling. Sampel dalam penelitian ini adalah siswa kelas Vc SDN 4 Sanur dengan jumlah 35 siswa sebagai kelompok eksperimen dan siswa kelas V SDN 8 Sanur dengan jumlah 41 siswa sebagai kelompok kontrol. Data kompetensi pengetahuan IPA dikumpulkan dengan instrumen berupa tes objektif pilihan ganda biasa berjumlah 32 butir tes yang telah divalidasi. Data yang diperoleh dianalisis dengan menggunakan metode statistik deskriptif dan statistik inferensial kemudian uji hipotesis menggunakan uji t. Hasil analisis data diperoleh $t_{\text {hitung }}=5,955$ sedangkan pada taraf signifikansi $5 \%$ dan $\mathrm{dk}=74$ diperoleh nilai $t_{\text {tabel }}=2,000$ sehingga $t_{\text {hitung }}=5,955>t_{\text {tabel }}=2,000$. Rerata kompetensi pengetahuan IPA siswa kelompok eksperimen $\bar{X}=78,00>\bar{X}=67,28$ kelompok kontrol. Dengan demikian dapat disimpulkan, bahwa pendekatan CTL berbasis penilaian portofolio berpengaruh terhadap kompetensi pengetahuan IPA siswa kelas V Gugus I Gusti Ngurah Rai Denpasar Selatan Tahun Ajaran 2017/2018.
\end{abstract}

Kata kunci: CTL, penilaian portofolio, kompetensi pengetahuan IPA.

\begin{abstract}
This research has an aim to determine the impact of CTL approach based on the portfolio assessment on science knowledge competence of grade V students Gugus I Gusti Ngurah Rai Denpasar Selatan of the academic year 2017/2018. This type of research is an experiment using Nonequivalent control group design research plan. The population of this research is all grade $V$ students Gugus I Gusti Ngurah Rai with the total number of 263 students. The determination of the sample in this research is using random sampling technique with random class. The sample of the research is the student of grade Vc SDN 4 Sanur with the total amount 35 students as an experiment group and the grade $V$ student SDN 8 Sanur with the total of 41 students as a control group. The competence data of science knowledge competence was collected by instruments in the form of multiple choice objective tests with 32 test items that has been validated. The data obtained were analyzed using statistic-descriptive method and statistic-inferential method, afterwards hypothesis test using ( $t$ ) test. The result of the analysis data obtained thitung $=5,955$ meanwhile, at the level of significance $5 \%$ and $d k=74$ obtained score ttabel $=2,000$ therefore, thitung $=5,955>$ ttabel $=2,000$. The average of science knowledge competence of an experiment group student $=78,00>=67,28$ control group. Therefore, It can be concluded that the CTL approach based on the portfolio assessment has an effect on the science knowledge competence of the students of grade V Gugus I Gusti Ngurah Rai Denpasar Selatan Academic Year 2017/2018.
\end{abstract}

Keywords : CTL, portfolio assessment, science knowledge competence. 


\section{Pendahuluan}

Peningkatan sumber daya manusia yang berkualitas dapat terwujud dengan jalan peningkatan kualitas pendidikan. Dunia pendidikan harus mampu meyakini bahwa sumber daya manusia yang dihasilkan akan mempunyai kompetensi yang mampu bersaing di era global. Pendidikan merupakan sarana yang menumbuh kembangkan potensi-potensi kemanusiaan untuk bermasyarakat dan menjadi manusia yang sempurna. Pendidikan yang berkualitas merupakan syarat utama untuk mewujudkan kehidupan berwawasan luas, disiplin, beriman, bertakwa serta bertanggung jawab di dalam kehidupan sehingga dapat meningkatkan sumber daya manusia bangsa Indonesia.

Dalam Undang-Undang Sistem Pendidikan Nasional Nomor 20 Tahun 2003 bab II Pasal 3 yang menyatakan bahwa :

Pendidikan nasional berfungsi mengembangkan kemampuan dan membentuk watak seperti peradapan bangsa yang bermartabat dalam rangka mencerdaskan kehidupan bangsa, bertujuan untuk berkembangnya potensi peserta didik agar menjadi manusia yang beriman dan bertakwa kepada Tuhan Yang Maha Esa, berakhlak mulia, sehat, berilmu, cakap, kreatif, mandiri, dan menjadi warga Negara yang demokratis serta bertanggung jawab.

Tujuan pendidikan nasional dijadikan dasar dan pedoman dalam penyusunan kurikulum untuk semua jenis dan jenjang pendidikan. Kurikulum yang ditetapkan pada sistem pendidikan Indonesia ialah kurikulum 2013. Sekolah sebagai lembaga yang menyelenggarakan pendidikan diharapkan mampu mengembangkan pembelajaran yang sesuai dengan kurikulum 2013 karena proses pembelajaran sangat memiliki peran penting dalam menciptakan prestasi yang berkualitas. Keadaan sekolah dan kualitas pendidik merupakan faktor yang harus diperhatikan dalam pencapaian keberhasilan pembelajaran. Pendidik merupakan tenaga profesional yang bertugas merencanakan dan melaksanakan proses pembelajaran, menilai hasil pembelajaran, melakukan pembimbingan dan pelatihan, serta melakukan penelitian dan pengabdian kepada masyarakat. Sebagai pendidik yang cenderung lebih mengarah pada penanaman konsep dan nilai-nilai, menuntut keterampilan para guru dalam merancang, menyajikan serta mengevaluasi bahan dalam proses pembelajaran.

Proses pembelajaran merupakan komponen utama yang harus ditetapkan dalam proses pengajaran yang berfungsi sebagai indikator keberhasilan pendidikan. Keberhasilan suatu proses pembelajaran sangat ditentukan oleh faktor guru. Guru menempati posisi kunci dalam menciptakan suasana belajar yang kondusif dan menyenangkan agar mampu mengarahkan siswa mencapai tujuan secara optimal untuk membangun sikap positif dalam belajar, membangkitkan rasa ingin tahu, mendorong kemandirian, dan ketepatan logika intelektual. Guru adalah komponen yang sangat menentukan dalam implementasi suatu strategi pembelajaran. Keberhasilan implementasi suatu strategi pembelajaran akan tergantung pada kepiawaian guru dalam menggunakan model, teknik, dan taktik pembelajaran. Pada pelaksanaan pembelajaran di kelas guru harus mampu memilih teknik pembelajaran yang tepat dan bermakna karena cara guru dalam menyampaikan materi pelajaran sangat berpengaruh dalam proses pembelajaran dan minat siswa terhadap materi pelajaran yang diharapkan dapat meningkatkan motivasi serta kompetensi siswa.

Pembelajaran yang perlu dikembangkan dan diharapkan dapat meningkatkan kompetensi peserta didik yakni khususnya pada muatan materi IPA. IPA merupakan salah satu mata pelajaran pokok pada jenjang sekolah dasar. Untuk mengoptimalkan pendidikan IPA perlu ditanamkan sejak bangku sekolah dasar melalui pembelajaran di kelas, sebab IPA merupakan suatu mata pelajaran yang memberikan kesempatan siswa berpikir kritis dan objektif. Menurut Samatowa (2016:3) "IPA adalah pengetahuan yang rasional dan objektif tentang alam semesta dengan segala isinya". IPA juga merupakan ilmu yang bersifat empirik dan membahas tentang fakta serta gejala alam. Fakta dan gejala alam tersebut menjadikan pembelajaran IPA tidak hanya verbal tetapi juga faktual. Dengan muatan materi IPA di Sekolah Dasar diharapkan dapat melatih siswa untuk berpikir kritis serta objektif dan memberikan kesempatan kepada siswa untuk mengembangkan keterampilan-keterampilan 
proses karena dalam membangun pengetahuan berdasarkan pengamatan, pengalaman, penyusunan gagasan melalui suatu percobaan sangatlah penting. Pengalaman langsung yang memegang peranan penting sebagai pendorong lajunya perkembangan kognitif siswa.

Berdasarkan hasil observasi yang dilakukan pada tanggal 11 Januari 2018 dengan guru kelas V di masing-masing SD Gugus I Gusti Ngurah Rai Denpasar Selatan, dalam proses pembelajaran terutama pada muatan pembelajaran IPA yang diperoleh sebagian besar siswa masih di bawah KKM 70 yang mengakibatkan kompetensi pengetahuan IPA belum optimal. Dari 263 siswa terdapat 149 atau 56,65\% siswa yang mendapatkan nilai dibawah kkm, sedangkan siswa yang diatas kkm sebanyak 114 atau 43,35\%. Muatan pembelajaran IPA dianggap sulit oleh sebagian besar siswa mengakibatkan siswa masih belum memahami pelajaran dan siswa kurang antusias dalam mengikuti pelajaran. Hal ini disebabkan karena lemahnya pelaksanaan proses pembelajaran yang diterapkan oleh guru. Proses pembelajaran sebagian guru masih didominasi oleh metode-metode lama seperti seringnya penggunaan metode ceramah dan metode tanya jawab. Hal ini menyebabkan proses pembelajaran yang terjadi kurang mampu mengembangkan kemampuan berpikir siswa karena siswa cenderung pasif dan bosan serta kurang bersemangat untuk belajar.

Masih banyak faktor yang dapat mempengaruhi kompetensi pengetahuan IPA siswa dalam proses pembelajaran seperti kurangnya media yang digunakan serta keterampilan guru dalam mengelola kelas. Oleh karena itu, salah satu cara untuk meningkatkan kompetensi pengetahuan siswa yakni diperlukan adanya inovasi baru dalam proses pembelajaran IPA dengan menerapkan pembelajaran yang mampu meningkatkan kompetensi pengetahuan IPA siswa. Pada penelitian ini, salah satu pendekatan pembelajaran yang dapat diterapkan untuk mengoptimalkan kompetensi pengetahuan IPA siswa yaitu pendekatan Contextual Teaching and Learning (CTL) Berbasis Penilaian Potofolio.

Menurut Ngalimun (2015:230) pembelajaran kontekstual adalah pembelajaran yang dimulai dengan sajian atau tanya jawab lisan (ramah, terbuka, negosiasi) yang terkait dengan dunia nyata kehidupan siswa (daily life modeling), sehingga akan terasa manfaat dari materi yang akan disajikan, motivasi belajar muncul, dunia pikiran siswa menjadi konkret, dan suasana menjadi kondusif dan menyenangkan. Prinsip pembelajaran kontekstual adalah aktivitas siswa melakukan dan mengalami, tidak hanya mencatat, dan pengembangan kemampuan sosialisasi. Melalui pembelajaran kontekstual, mengajar bukan transformasi pengetahuan dari guru kepada siswa dengan menghafal sejumlah konsepkonsep yang terlepas dari kehidupan nyata, akan tetapi lebih ditekankan pada upaya memfasilitasi siswa untuk mencari kemampuan dari apa yang dipelajarinya.

CTL adalah sebuah sistem yang merangsang otak untuk menyusun pola-pola yang mewujudkan makna. Shoimin (2014:44) menyatakan beberapa keunggulan pembelajaran CTL yaitu: a) Pembelajaran kontekstual dapat menekankan aktivitas berpikir siswa secara penuh, baik fisik maupun mental. b) Pembelajaran kontekstual dapat menjadikan siswa belajar bukan dengan menghafal, melainkan proses berpengalaman dalam kehidupan nyata.c) Kelas dalam kontekstual bukan sebagai tempat untuk memperoleh informasi, melainkan sebagai tempat untuk menguji data hasil temuan mereka di lapangan.d) Materi pelajaran ditentukan oleh siswa sendiri, bukan hasil pemberian dari orang lain.

Rusman (2014:191) menyatakan ciri khas CTL ditandai oleh tujuh komponen utama sebagai berikut. a) Konstruktivisme (Constructivism) adalah landasan berpikir (filosofi) dalam CTL, yaitu bahwa pengetahuan dibangun oleh manusia sedikit demi sedikit yang hasilnya diperluas melalui konteks yang terbatas. Dalam pembelajaran siswa membangun sendiri pengetahuan mereka melalui keterlibatan aktif dalam proses belajar dan mengajar. b) Menemukan (Inquiry) merupakan kegiatan inti dari CTL, melalui upaya menemukan dan keterampilan yang diperoleh siswa diharapkan bukan hasil mengingat seperangkat faktafakta, tetapi hasil dari menemukan sendiri. c)Bertanya (Questioning) merupakan strategi utama dalam CTL, bertanya dalam pembelajaran merupakan kegiatan untuk mendorong, membimbing, dan menilai kemampuan berpikir siswa. d) Masyarakat Belajar (Learning Community) adalah membiasakan siswa untuk melakukan kerja sama dan memanfaatkan sumber belajar dari teman-teman belajarnya. e) Pemodelan (Modelling) merupakan dalam 
sebuah pembelajaran keterampilan atau pengetahuan tertentu, ada model yang bisa ditiru, pemodelan dapat berbentuk demonstrasi, pemberian contoh tentang konsep atau aktivitas belajar. f) Refleksi (Reflection) adalah gambaran terhadap kegiatan atau pengetahuan yang baru saja diterima, siswa diberi kesempatan untuk mencerna, menimbang, membandingkan, menghayati, dan melakukan diskusi dengan dirinya sendiri (learning to be). g) Penilaian Sebenarnya (Authentic Assessment) merupakan tahap terakhir dari pembelajaran kontekstual, penilaian adalah proses pengumpulan berbagai data dan informasi yang bisa memberikan gambaran atau petunjuk terhadap pengalaman belajar siswa.

Pada setiap kesempatan pembelajaran siswa diberi kesempatan untuk mencerna, menimbang, membandingkan, menghayati, dan melakukan diskusi dengan dirinya sendiri. Tahap terakhir dari pembelajaran kontekstual adalah melakukan penilaian. Dengan berbasis penilaian portofolio akan mempermudah untuk mendapatkan informasi kualitas proses dan hasil pembelajaran. Penilaian Portofolio adalah suatu pendekatan atau model penilaian yang bertujuan untuk mengukur kemampuan siswa dalam membangun dan merefleksi suatu pekerjaan/tugas atau karya melalui pengumpulan bahan-bahan yang relevan dengan tujuan dan keinginan yang dibangun oleh siswa, sehingga hasil pekerjaan tersebut dapat dinilai dan dikomentari oleh guru dalam periode tertentu (Arifin 2012:198). Menurut Yus (2006:74) Penilaian portofolio bertujuan sebagai alat penilaian formatif maupun sumatif. Portofolio sebagai alat penilaian formatif digunakan unttuk memantau kemajuan peserta didik belajar dari hari ke hari sekaligus mendeteksi kemungkinan terjadi kesulitan belajar.

Pembelajaran CTL berbasis penilaian portofolio menekankan kepada siswa untuk mencari, mengolah, dan menemukan pengalaman belajar yang bersifat konkret (terkait dengan kehidupan nyata) serta melalui penilaian portofolio memberikan kesempatan peserta didik untuk lebih banyak terlibat, dan peserta didik sendiri dapat dengan mudah mengontrol sejauh mana perkembangan kemampuan yang telah diperolehnya.

Berdasarkan uraian di atas banyak hal yang bisa siswa dapatkan dalam proses pembelajaran sehingga dapat mempengaruhi peningkatan kompetensi pengetahuan IPA. Maka perlu ditindak lanjuti dengan melakukan penelitian yang berjudul "Pengaruh Pendekatan CTL Berbasis Penilaian Portofolio terhadap Kompetensi Pengetahuan IPA kelas V Gugus I Gusti Ngurah Rai Tahun Ajaran 2017/2018.

\section{Metode}

Penelitian ini dilaksanakan pada kelas V Gugus I Gusti Ngurah Rai Kecamatan Denpasar Selatan Tahun Ajaran 2017/2018. Penelitian ini bertujuan untuk mengetahui kompetensi pengetahuan IPA antara kelompok siswa yang dibelajarkan dengan pendekatan CTL berbasis penilaian portofolio dengan kelompok siswa yang dibelajarkan dengan pembelajaran konvensional. Rancangan penelitian yang digunakan dalam penelitian ini adalah Nonequivalent Control Grup Design. Langkah-langkah dalam rancangan ini pada dasarnya sama seperti rancangan pretest-posttest control group design (Sugiyono, 2017:76). Rancangan penelitian ini dikategorikan sebagai rancangan eksperimen kuasi (quasi experimental design).

Populasi adalah wilayah generalisasi yang terdiri atas obyek/subyek yang mempunyai kualitas dan karakteristik tertentu yang diterapkan oleh peneliti untuk dipelajari dan kemudian ditarik kesimpulannya"(Sugiyono,2017:80).Sedangkan Agung (2014:69) mengungkapkan bahwa populasi adalah keseluruhan obyek dalam suatu penelitian. Jadi berdasarkan kedua pendapat tersebut dapat disimpulkan bahwa populasi adalah keseluruhan wilayah generalisasi yang terdiri atas obyek/subyek dalam suatu penelitian yang mempunyai kualitas dan karakteristik tertentu untuk dipelajari dan kemudian ditarik kesimpulannya. Populasi dalam penelitian ini seluruh siswa kelas V SD Gugus I Gusti Ngurah Rai Kecamatan Denpasar Selatan Tahun Ajaran 2017/2018 yang berjumlah 274 siswa yang terbagi dalam 5 SD Negeri dan 1 SD Swasta, yaitu: SDN 1 Sanur, SDN 3 Sanur, SDN 4 Sanur, SDN 8 Sanur, SDN 11 Sanur, SD Bina Tunas. Namun dalam penelitian ini hanya melakukan penelitian di SD Negeri saja, karena di SD Swasta tidak menggunakan kurikulum 2013. 
Sampel adalah sebagian dari populasi yang diambil, yang dianggap mewakili seluruh populasi dan diambil dengan menggunakan teknik tertentu (Agung, 2014:69). Bila populasi besar, dan peneliti tidak mungkin mempelajari semua yang ada pada populasi, misalnya karena keterbatasan dana, tenaga dan waktu, maka peneliti dapat menggunakan sampel yang diambil dari populasi itu (Sugiyono, 2017:81). Jadi dapat disimpulkan sampel merupakan suatu kelompok yang lebih kecil atau bagian dari populasi untuk dijadikan sebagai sumber data penelitian. Teknik sampel yang digunakan dalam penelitian ini adalah teknik Random Sampling. Menurut Agung (2014:72) random sampling merupakan cara pengambilan sampel dengan memberikan kesempatan yang sama kepada anggota populasi untuk diambil menjadi anggota sampel. Dalam menentukan kelas yang setara dari segi akademik, maka pengambilan sampel dengan teknik random sampling dapat dilakukan dengan cara undian (Agung, 2014:72). ). Langkah-langkah penentuan sampel adalah sebagai berikut.

Pada tahap pertama, dilakukan teknik pengambilan sampel dengan cara undian, sehingga semua anggota populasi memiliki kesempatan yang sama untuk dipilih menjadi sampel penelitian. Cara undian dilakukan dengan menulis semua nama kelas $\mathrm{V}$ di seluruh SD populasi pada masing-masing kertas yang jumlahnya 7 kelas, kemudian kertas digulung dan dimasukan ke dalam kotak dan dikocok untuk memilih dua kelas yang dijadikan sampel penelitian.

Pada tahap kedua, dilakukan uji kesetaraan sampel dengan diberikan pretes kepada dua kelas yang terpilih melalui pengundian. Nilai satau skor hasil pretes tersebut diuji kesetaraannya menggunakan uji-t, kemudian sampel itu diundi untuk memilih kelas yang digunakan sebagai kelompok kontrol dan kelompok eksperimen. Untuk menguji kesetaraan sampel diuji dengan rumus uji-t yakni dengan polled varian.

Metode pengumpulan data adalah proses pengumpulan data yang dilakukan oleh peneliti. Pada penelitian ini metode pengumpulan data yang digunakan adalah metode tes. Menurut Sudijono (2013:66) tes adalah alat atau prosedur yang dipergunakan dalam rangka pengukuran dan penilaian. Berdasarkan pada metode pengumpulan data, instrumen yang digunakan untuk mengumpulkan data kompetensi pengetahuan IPA adalah tes objektif dalam bentuk pilihan ganda biasa (Multiple Choice Test). Suharsimi (2015:183) menyatakan Multiple choice test terdiri atas suatu keterangan atau pemberitahuan tentang suatu pengertian yang belum lengkap.

Uji hipotesis yang dilakukan dalam penelitian ini menggunakan analisis uji-t. Data penelitian harus memenuhi uji prasyarat analisis yakni dengan melakukan uji normalitas sebaran data dan uji homogenitas varians.

\section{Hasil dan Pembahasan}

Data yang dianalisis dalam penelitian ini diperoleh dari data hasil kompetensi pengetahuan siswa yang mengikuti pembelajaran pendekatan CTL berbasis penilaian portofolio pada kelas eksperimen dan pembelajaran konvensional pada kelas kontrol. Rekapitulasi perhitungan data hasil penelitian tentang kompetensi pengetahuan IPA siswa dapat dilihat pada tabel 1. Data yang diperoleh dalam uji prasyarat analisis yang mencakup uji normalitas dan uji homogenitas. Uji normalitas data dilakukan untuk mengetahui sebaran data hasil penelitian berdistribusi normal atau tidak. Uji normalitas data kompetensi pengetahuan IPA siswa mempergunakan rumus analisis Chi-Kuadrat (X2) pada taraf signifikansi $5 \%$ dan derajat kebebasan $(\mathrm{dk})=\mathrm{n}-1$. Harga X2hit yang diperoleh dari kelompok eksperimen adalah X2hit $==4,56$. Harga tersebut kemudian dengan harga X2tabel dengan $\mathrm{dk}=5$ dan taraf signifikansi $5 \%$ sehingga diperoleh harga X2tabel $=11,07$, karena X2hitung < X2tabel $(4,56<11,07)$. Hal ini menunjukkan sebaran data kompetensi pengetahuan IPA kelompok eksperimen berdistribusi normal. Selanjutnya Harga X2hit yang diperoleh dari kelompok kontrol adalah X2hit $==9,78$. Harga tersebut kemudian dengan harga $X 2$ tabel dengan $\mathrm{dk}=5$ dan taraf signifikansi $5 \%$ sehingga diperoleh harga $\mathrm{X} 2$ tabel $=$ 11,07 , karena X2hitung < X2tabel $(9,78<11,07)$. Hal ini menunjukkan sebaran data kompetensi pengetahuan IPA kelompok kontrol berdistribusi normal. 
Selanjutnya dilakukan uji homogenitas varians terhadap varians antar kelas eksperimen dan kelas kontrol. homogenitas dilakukan untuk mengetahui apakah varians data dari kelompok sampel yang dianalisis homogen atau tidak. Jumlah masing-masing unit analisis adalah 35 untuk kelompok eksperimen dan 41 untuk kelompok kontrol. Untuk menentukan homogenitas variannya menggunakan uji F. Ketentuan harga Fhitung yang diperoleh dibandingkan dengan harga Ftabel pada taraf signifikansi $5 \%$ dengan derajat kebebasan untuk pembilang $(\mathrm{dk})=(\mathrm{n} 1-1)=(41-1)$ dan derajat kebebasan untuk penyebut $(\mathrm{dk})=(\mathrm{n} 2-1)=(35-1)$. Dari hasil analisis, uji homogenitas varians menunjukkan bahwa Fhitung $=1,51$ dan Ftabel $=1,74$ sehingga Fhitung $<$ Ftabel. Ini berarti bahwa varians antara kelas eksperimen dan kelas kontrol homogen.

Hasil uji prasyarat yang telah dilaksanakan menunjukkan bahwa uji hipotesis dapat dilakukan karena data telah berdistribusi normal dan homogen. Hipotesis yang diajukan diuji menggunakan uji-t dengan rumus polled varians. Uji hipotesis dilakukan pada taraf signifikansi $5 \%$ dengan kaidah hipotesis $\mathrm{HO}$ ditolak dan Ha diterima jika thitung $>$ ttabel dan HO diterima dan Ha ditolak jika thitung < ttabel. . Hasil perhitungan uji hipotesis disajikan dalam tabel 1.

Tabel 1. Rangkuman Hasil Perhitungan Uji-t

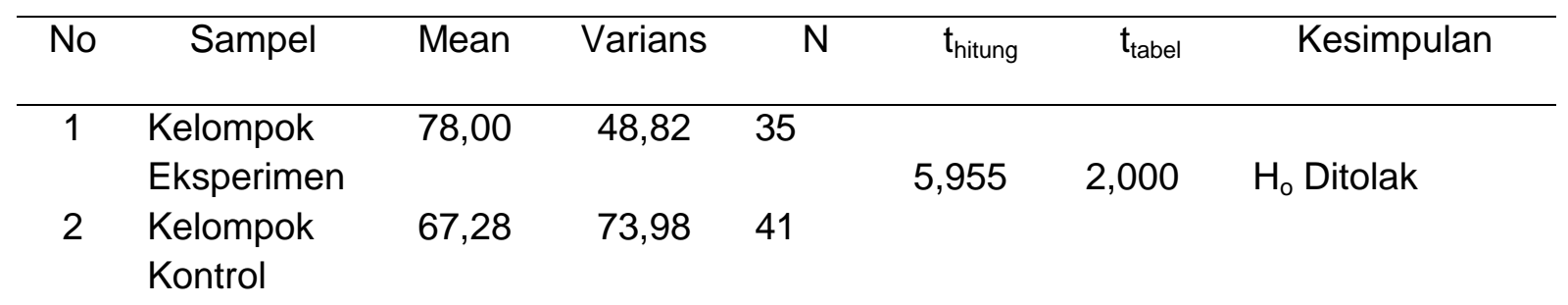

Berdasarkan hasil perhitungan uji-t, diperoleh $t_{\text {hitung }}=5,955$ dan untuk taraf signifikansi $5 \%$ dengan $\mathrm{dk}=(35+41-2=74)$ diperoleh $t_{\text {tabel }}=2,000$. Karena $t_{\text {hitung }}>t_{\text {tabel }}(5,955>2,000)$ maka $\mathrm{H}_{0}$ yang menyatakan "tidak terdapat pengaruh pendekatan CTL berbasis penilaian portofolio terhadap kompetensi pengetahuan IPA siswa kelas V Gugus I Gusti Ngurah Rai Denpasar Selatan Tahun Ajaran 2017/2018“, ditolak dan $\mathrm{H}_{\mathrm{a}}$ yang menyatakan " terdapat pengaruh pendekatan CTL berbasis penilaian portofolio terhadap kompetensi pengetahuan IPA siswa kelas V Gugus I Gusti Ngurah Rai Denpasar Selatan Tahun Ajaran 2017/2018", diterima.

Berdasarkan hasil analisis data, diperoleh $t_{\text {hitung }}=5,955$. Harga tersebut kemudian dibandingkan dengan harga $t_{\text {tabel }}$ dengan $\mathrm{dk}=35+41-2=74$ dan taraf signifikansi $5 \%$ sehingga diperoleh harga $t_{\text {tabel }}=2,000$, sehingga $t_{\text {hitung }}=5,955>t_{\text {tabel }}=2,000$. Dengan demikian, hipotesis nol $\left(\mathrm{H}_{0}\right)$ ditolak. Hal ini berarti terdapat pengaruh pendekatan CTL berbasis penilaian portofolio terhadap kompetensi pengetahuan IPA siswa kelas V Gugus I Gusti Ngurah Rai Denpasar Selatan Tahun Ajaran 2017/2018.

Perolehan hasil perhitungan analisis data yang diperoleh diperoleh nilai rata-rata kelompok eksperimen $\bar{X}=78,00$ dan kelompok kontrol $\bar{X}=67,28$. Ini menunjukkan bahwa nilai rata-rata kelompok eksperimen $\bar{X}=78,00>\bar{X}=67,28$ kelompok kontrol. Dengan demikian, pendekatan CTL berbasis penilaian portofolio berpengaruh terhadap kompetensi pengetahuan IPA siswa kelas V Gugus I Gusti Ngurah Rai Denpasar Selatan Tahun Ajaran 2017/2018.

Pendekatan CTL berbasis penilaian portofolio berpengaruh terhadap kompetensi pengetahuan IPA disebabkan karena adanya perbedaan perlakuan pada langkah-langkah pembelajaran. Pada kelompok eksperimen yang diberikan perlakuan pendekatan CTL berbasis penilaian portofolio yaitu adanya unsur pembelajaran kontekstual menjadikan siswa lebih termotivasi dan mendorong siswa aktif dalam memompa kemampuan diri tanpa merugi dari segi manfaat, sebab siswa berusaha mempelajari konsep sekaligus menerapkan dan 
mengaitkannya dengan dunia nyata, sehingga dapat meningkatkan minat belajar siswa yang pada akhirnya berpengaruh terhadap kompetensi pengetahuan siswa. Adapun komponen yang diterapkan dalam pendekatan CTL adalah 1) Siswa bekerja sendiri dan mengkonstruksi sendiri pengetahuan, 2) Siswa menemukan sendiri permasalahan yang ada, 3) Siswa diberikan kesempatan untuk bertanya kepada guru tentang masalah yang ditemukan, 4) Membuat kelompok belajar siswa untuk membahas masalah yang ditemukan, 5) Guru menghadirkan model sebagai media pembelajaran, 6) Siswa merefleksi dan menyimpulkan apa yang sudah dipelajari, 7) Guru melakukan penilaian terhadap hasil belajar siswa, hal ini didukung oleh Rusman (2014:192). Melalui pembelajaran kontekstual, mengajar bukan transformasi pengetahuan dari guru kepada siswa dengan menghafal sejumlah konsepkonsep yang terlepas dari kehidupan nyata, akan tetapi lebih ditekankan pada upaya memfasilitasi siswa untuk mencari kemampuan dari apa yang dipelajarinya. Hal tersebut didukung oleh Shoimin (2014:44) yang menyatakan keunggulan CTL adalah dapat menjadikan siswa belajar bukan dengan menghafal, melainkan proses berpengalaman dalam kehidupan nyata. Selain dengan penerapan pembelajaran CTL, penerapan pembelajaran di kelas perlu dibantu dengan penggunaan penilaian autentik salah satunya penilaian portofolio. Penilaian portofolio merupakan penilaian yang terdiri dari kumpulan hasil karya siswa yang disusun secara sistematik dalam jangka waktu tertentu. Dengan adanya penilaian portofolio siswa akan mampu untuk menilai sendiri perkembangan kemampuan belajar melaui karya dan usaha yang telah dikerjakan.

Sedangkan pembelajaran tersebut berbeda dengan perlakuan yang diberikan pada kelompok kontrol yang pembelajarannya dirancang oleh guru dengan media yang digunakan hanya sebatas seperti buku pegangan saja tanpa menggunakan media tambahan. Hal ini menyebabkan pembelajaran yang dilakukan guru sifatnya monoton sehingga siswa merasa bosan dan kurang terlibat aktif dalam proses pembelajaran. Pada kelompok kontrol pembelajaran yang dilaksanakan adalah menggunakan pendekatan saintifik. Pembelajaran pada kelompok eksperimen dan kelompok kontrol sama-sama menggunakan pendekatan, tetapi yang membedakan di kelas eksperimen menggunakan pendekatan CTL yang sudah memiliki komponen belajar yang akan diterapkan yang menjadikan pembelajaran lebih menarik, menyenangkan sehingga mampu membangkitkan minat siswa untuk belajar.

Berdasarkan pemaparan diatas pendekatan CTL berbasis penilaian portofolio dapat meningkatkan kompetensi pengetahuan IPA siswa. Hal ini terjadi karena penerapan pendekatan CTL berbasis penilaian portofolio memberikan memberikan fasilitas kegiatan belajar siswa dalam mengumpulkan hasil karya dengan mencari, mengolah dan menemukan pengalaman yang bersifat konkret, dengan melalui kumpulan hasil karya siswa dapat menilai sendiri perkembangan kemampuan belajar melaui karya dan usaha yang telah dikerjakan.

Hasil penelitian ini diperkuat oleh simpulan yang disampaikan oleh Yulistya (2013) dengan judul "Pengaruh Pendekatan CTL Berbantuan Penilaian Kinerja Terhadap Pemahaman Konsep IPA Siswa Kelas V SD Negeri 1 Sangsit", demikian pula penelitian yang dilakukan oleh Hermawan (2013) dengan judul "Pengaruh Pendekatan Contextual Teaching and Learning (CTL) Berbasis Kearifan Lokal Terhadap Hasil Belajar IPS Siswa Kelas IV SD".

Jadi dapat disimpulkan bahwa penerapan pendekatan CTL berbasis penilaian portofolio berpengaruh terhadap kompetensi pengetahuan IPA siswa kelas V Gugus I Gusti Ngurah Rai Kecamatan Denpasar Selatan Tahun Ajaran 2017/2018.

\section{Simpulan dan Saran}

Sesuai dengan hasil penelitian dan pembahasan, maka dapat disimpulkan sebagai berikut. 1) Berdasarkan hasil analisis data kompetensi pengetahuan IPA pada kelompok eksperimen yang dibelajarkan melalui pendekatan CTL berbasis penilaian portofolio diperoleh rerata sebesar 78,00. Berdasarkan rata-rata yang diperoleh kelompok eksperimen, menunjukkan hasil kompetensi pengetahuan IPA siswa sudah di atas KKM 70. 2) Berdasarkan hasil analisis data kompetensi pengetahuan IPA pada kelompok kontrol yang dibelajarkan melalui pembelajaran konvensional diperoleh rerata sebesar 67,28. 
Berdasarkan rata-rata yang diperoleh kelompok kontrol, menunjukkan hasil kompetensi pengetahuan IPA siswa masih di bawah KKM 70. 3) Rerata kompetensi pengetahuan IPA siswa yang diperoleh pada kelompok eksperimen yang dibelajarkan melalui pendekatan CTL berbasis penilaian portofolio $=78,00>=67,28$ rerata kompetensi pengetahuan IPA siswa kelompok kontrol yang dibelajarkan melalui pembelajaran konvensional. Berdasarkan hasil analisis uji t diperoleh thitung $=5,955$. Harga tersebut kemudian dibandingkan dengan harga ttabel pada taraf signifikansi $5 \%$ dengan $\mathrm{dk}=\mathrm{n} 1+\mathrm{n} 2-2=35+41-2=74$ adalah 2,000. Oleh karena thitung $>$ ttabel $(5,955>2,000)$ maka Ho ditolak atau Ha diterima. Hal ini berarti terdapat pengaruh pendekatan CTL berbasis penilaian portofolio terhadap kompetensi pengetahuan IPA siswa kelas V Gugus I Gusti Ngurah Rai Denpasar Selatan Tahun Ajaran 2017/2018.

Berdasarkan simpulan yang telah dipaparkan, maka saran yang dapat diajukan adalah sebagai berikut. Kepada guru agar lebih kreatif dalam mengembangkan inovasi pembelajaran dengan menerapkan strategi, pendekatan, model dan metode yang mampu mengoptimalkan kompetensi pengetahuan siswa. Salah satu desain pembelajaran yang mampu meningkatkan kompetensi pengetahuan IPA siswa adalah dengan menerapkan pendekatan CTL berbasis portofolio.

Berdasarkan temuan penelitian, kepada kepala sekolah sebaiknya agar dapat memperbaiki kualitas pembelajaran dengan memberikan sosialiasi secara berkelanjutan mengenai inovasi-inovasi pembelajaran untuk meningkatkan mutu muatan materi IPA pada khususnya dan semua muatan materi pada umumnya.

Dilakukannya penelitian ini, disarankan agar hasil penelitian ini dapat dijadikan referensi atau sebagai informasi awal bagi peneliti lain untuk melakukan penelitian lebih lanjut dengan menggunakan pendekatan CTL berbasis penilaian portofolio

\section{Daftar Rujukan}

Agung, A.A. Gede. 2014. "Metodologi Penelitian Pendidikan". Singaraja : Aditya Media Publising

Alwasilah,Chaedar. 2012. "Contextual Teaching and Learning (Menjadikan Kegiatan Belajar-Mengajar Mengasyikkan dan Bermakna)". Bandung: Mizan Media Utama

Arifin, Zainal. 2012. “Evaluasi Pembelajaran”. Bandung: PT Remaja Rosdakarya.

Arikunto, Suharsimi. 2015. "Dasar-Dasar Evaluasi Pendidikan”. Jakarta: Bumi Aksara.

Dewantara, D. (2014). Penerapan Model Pembelajaran Problem Based Learning Untuk Meningkatkan Aktivitas Dan Hasil Belajar Siswa Pada Pelajaran IPA (Studi Pada Siswa Kelas V SDN Pengambangan 6 Banjarmasin). Jurnal Paradigma Volume 11 Nomor 2 Juli 2016, 41 - 44.

Hidayat, W. (2016). Penerapan Model Problem Based Learning Untuk Meningkatkan Hasil Belajar Ipa Siswa Kelas Vb Sdn 1 Cakranegara Tahun Ajaran 2015/2016. 1 - 14.

Indah, N. (2015). Meningkatkan Prestasi Belajar IPA Materi Pokok Sumber Energi Gerak Melalui Penerapan Model Pembelajaran Problem Based Learning (PBL) Pada Siswa Kelas I.A SD Negeri 9 Kabangka Tahun Ajaran 2014/2015. 50 - 55.

Koyan, I Wayan. 2007. "Statistika Terapan (Teknik Analisis Data Kuantitatif)". Singaraja: Universitas Pendidikan Ganesha

Kunandar, 2014. "Penilaian Autentik (Penilaian Hasil Belajar Peserta Didik Berdasarkan Kurikulum 2013)”. Jakarta: Rajawali.

Ngalimun. 2015. "Strategi dan Model Pembelajaran".Yogyakarta. Aswaja Pressindo. 
Rusman. 2014. "Model-Model Pembelajaran”. Jakarta: Rajawali.

Samatowa,Usman.2016. “Pembelajaran IPA di Sekolah Dasar”. Jakarta Barat: Permata Puri Media.

Setyosari, Punaji. 2015. "Metode Penelitian Pendidikan \& Pengembangan ". Jakarta: Kencana Prenada Media Group.

Sohimin, Aris. 2014. "68 Model Pembelajaran Inovatif dalam Kurikulum 2013 ". Yogyakarta: Ar- Ruzz Media

Sudijono, Anas. 2013. "Pengantar Evaluasi Pendidikan”. Jakarta: Rajawali

Sugiyono. 2017. "Metode Penelitian Kuantitatif Kualitatif dan R\&D”. Bandung: Alfabeta.

Sugiyono. 2012. "Statistika untuk Penelitian". Bandung: Alfabeta.

Susanto, Ahmad. 2015. “Teori Belajar dan Pembelajaran di Sekolah Dasar ”. Jakarta: Prenada Media Group.

Suwandi, Y. (2015). Peningkatan Hasil Belajar IPA Tentang Ekosistem Melalui Metode Problem Based Learning Pada Siswa Kelas V Sekolah Dasar Kabupaten Tana Tidung. Jurnal Pendidikan Dasar Volume 6 Edisis 1 mei 2015, 93 - 102.

Trianto. 2009. Mendesain Model Pembelajaran Inovatif- Progresif: Konsep Landasan Teoritis-Praktis dan Implementasinya. Jakarta: Prenada Media Group.

Yulistya. 2013. "Pengaruh Pendekatan CTL Berbantuan Penilaian Kinerja Terhadap Pemahaman Konsep IPA Siswa Kelas V SD Negeri 1 Sangsit”. e-Journal Program Pascasarjana Universitas Pendidikan Ganesha Program Studi Pendidikan Dasar (Volume 4). Tersedia pada https://ejournal.undiksha.ac.id/index.php/JJPGSD/article/view/732/605 (diakses tanggal 2 mei 2018)

Yus, Anita. 2006. "Penilaian Portofolio untuk Sekolah Dasar". Departemen Pendidikan Nasional 